SCIREA Journal of Health

http://www.scirea.org/journal/PMH

November 10, 2021

Volume 5, Issue 6, December 2021

SCIREA

\title{
COVID-19 PREVENTIVE PRACTICE AND EXPERIENCE OF VIOLENCE AGAINST WOMEN AND GIRLS IN NIGERIA
}

Ibekwe Ogechukwu C. MPH, BNSC. ${ }^{1}$ Kareem Abiodun J. FMCPaed, MPH, MBChB. ${ }^{2 *}$ Akpoti Okehi O. MBBS. ${ }^{3}$ Ogunromo Ayodele Y. MPH, BSc ${ }^{4}$

${ }^{1}$ Institute of Human Virology, Abuja, Nigeria. Email- gechi012@gmail.com.

${ }^{2}$ Department of Paediatrics. Federal Medical Centre, Owo, Ondo State, Nigeria. Emailbiodunkareem13@gmail.com Orchid number- https://orchid.org/0000-0002-2565-08881

${ }^{3}$ Clinton Health Access Initiative, Abuja, Nigeria. Email-akpotio.en@gmail.com.

${ }^{4}$ Welfare Unit, Association of Resident Doctor; Federal Medical Centre, Owo, Ondo-State,

Nigeria. Email- Ayodele.ogunromo@gmail.com.

* Corresponding Author:

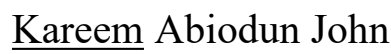

Department of Paediatrics; Federal Medical Centre, Owo, Ondo-State, Nigeria.

E-mail: biodunkareem13@gmail.com

Mobile phone number: +2348034319940 


\begin{abstract}
Introduction: This study aimed to assess COVID-19 preventive measures and violence against women and girls and determine the factors that contribute to COVID-19 preventive practices and violence against women and girls in Nigeria.

Method: A descriptive cross-sectional design was used for this study. Data was collected from 413 women/girls with age $\geq 18$ years using a semi-structured interviewer-administered questionnaire The data were analyzed using descriptive and inferential statistics. $\mathrm{P}$ value $<0.05$ was considered significant.
\end{abstract}

Results: Almost all 410 (99.2\%) of the women were aware of the COVID-19. The majority $313(75.8 \%)$ revealed that television was their main sources of information. Also, regular hand washing, 390 (94.4\%) and use of face masks, 322 (77.2\%) were the most common COVID-19 preventive measures practiced by the respondents. However, most $305(73.8 \%)$ of the respondents had poor COVID-19 preventive practice. Further results revealed that physical violence 338 (81.8\%) was the most common type of violence known. Thirty-one (7.5\%) of the women claimed they had experienced at least one type of violence as a result of staying at home during the COVID-19 lockdown. There was a significant relationship between the COVID-19 preventive measures and violence against women and girls $\left(\chi^{2}=\right.$ $19.59 ; p=0.001)$

Conclusion: The COVID-19 preventive practices such as lockdown enforcement contributes to violence against women and girls.

Keywords: COVID-19 Preventive Practice, Factors, Gender-based Violence, Nigeria.

\title{
Introduction
}

The outbreak of coronavirus-19 (COVID-19) has impacted the lifestyles of people all over the globe as well as the economies of virtually every country. Coronavirus-19 was declared an outbreak of public health emergency of international concern on 30th January 2020 and a pandemic on 11th March 2020 [1]. As the virus continues to spread, countries had taken several preventive practices to mitigate the effects of the outbreak as well as uphold the control measures [2,3]. Some of the preventive measures include regular hand washing with soap and water or using an alcohol-based hand rub, maintaining social distancing of more 
than 2 metres from persons, the avoidance of touching one's face, practicing respiratory hygiene such as cough etiquettes, wearing a surgical mask and staying at home [3].

Violence against women and girls (VAWG) is any public or private act of gender-based violence that can cause physical, sexual, or psychological harm or suffering to women and girls which can include coercion, threatening or the deprivation of free will in households or community as a whole [4]. It includes intimate partner violence, non-partner sexual violence, early and forced marriage, trafficking, female genital mutilation and honour killings [5]. The incidence of VAWG is underreported and as such it poses serious health and socio-economic consequences for family, society and country [4-6]. Violence against women and girls is not limited by race, location or age as it affects women all over the world and it is a global human rights violation [7].

More than $30 \%$ of women globally have experienced different form of violence be it physical or sexual violence, while $7 \%$ have experienced sexual assaults from non-partners [8]. About 140 million girls and women around the world have undergone female genital mutilation (FGM) and over 3 million are exposed to FGM annually in Africa alone [9,10]. Up to 70 million under-age girls have been forcefully married globally [11].

The COVID-19 pandemic presents tougher conditions for most families and thus increases the risk of violence against women and girls [6]. Violence against women and girls increases when there are interruption of social and preventive channels, stress and restricted access to services [4]. The aforementioned is not unexpected during the COVID-19 preventive practices such as maintaining social distancing, staying at home and restriction of movement $[2,5]$. Therefore, there is need to assess the impact of COVID-19 prevention practices on violence against women and girls.

\section{Method}

This study was conducted in Ibadan, Oyo State, southwestern part of Nigeria with a population of over six million people making it the third highest populated city in Nigeria [12]. Ibadan is mostly dominated by the Yoruba tribe although other tribes are also inhabitants of the city such as the Igbos, Fulanis, and Hausas [13]. Ibadan, Oyo-State is the largest city in West Africa covering a total area of 3,080 sqm and $275 \mathrm{~m}$ above sea level. The city of Ibadan is $120 \mathrm{~km}$ northeast of Lagos State and $530 \mathrm{~km}$ southwest of the Federal Capital Territory, 
Abuja [14]. Ibadan has a total of eleven local government areas (LGA) comprising of five urban and six semi-urban Local Government Areas.

The descriptive cross-sectional study was conducted between January 5, 2021 and July 31, 2021. Ethical approval was obtained from the Department of Planning, Research and Statistics Division Ministry of Health, Oyo State with the reference number AD 13/479/2060. Permission was obtained from the head of each community of the four selected LGAs. Written informed consent was obtained from the respondents for the study. The respondents were assured of the confidentiality of the information given and the data collected were entered and kept in a password protected computer.

Four hundred and thirteen respondents were recruited for the study using a multistage sampling method across the LGAs in Ibadan. The number allocated to each household was determined using the formula $n / N \times 413$, where $n$ is the number in each household and $N$ is the total number of women/girls [15]. Consenting women/girls who are 18years and above filled a pretested semi-structured questionnaire. The questionnaire was written in English and Yoruba. While an interpreter/assistance assisted those who could neither read, write nor understand either language. The questionnaires entailed sections on the respondents' sociodemographic characteristics, information on COVID-19 preventive practices, violence experienced by respondents during the COVID-19 lockdown and factors that contribute to the violence. Internal consistency using Cronbach's Alpha was done and reliability coefficient of 0.70 was recorded after the test which indicates a high internal consistency, hence, considered acceptable.

The data obtained from the questionnaires was analysed using the Statistical Package for Social Sciences (SPSS) for Windows version 23. Descriptive and inferential statistics were done. Chi-square $\left(\chi^{2}\right)$ was used to compare level of COVID-19 preventive practice and experience of VAWG. Factors associated with COVID-19 preventive practice and experience of VAWG were done using Chi-square $\left(\chi^{2}\right)$. Results were considered to be significant at $p \leq$ 0.05 .

\section{Results}

Four hundred and thirteen completely filled questionnaires were analysed. The age range of respondents was 18-52 years with mean age of 29.9 (7.8) years. The sociodemographic characteristics of the respondents is shown in table 1. The age group 18-29 years accounted 
for more than half, $223(54.0 \%)$ of the respondents. Majority, $216(52.3 \%)$ of the respondent highest level of education was tertiary education. More than three-quarters, 324 (78.4\%) were married while more than one-third, $143(34.6 \%)$ of the respondents were traders. Almost all, $410(99.2 \%)$ of the respondents were aware of COVID-19 disease and the main source of information was television, $313(75.8 \%)$ closely followed by radio $287(69.5 \%)$ as seen in table 2. About three-quarters, 305 (73.8\%) of the respondents had poor COVID-19 preventive practice as shown in Fig 1.

Table 1: Socio-demographic Characteristics of Respondents

\begin{tabular}{|c|c|c|}
\hline Variable & $\begin{array}{c}\text { Frequency } \\
(n=413)\end{array}$ & Percentage \\
\hline \multicolumn{3}{|l|}{ Age (in group) } \\
\hline $18-29$ years & 223 & 54.0 \\
\hline $30-39$ years & 156 & 37.8 \\
\hline 40 and above & 34 & 8.2 \\
\hline \multicolumn{3}{|l|}{ Educational level } \\
\hline Primary education & 21 & 5.1 \\
\hline Secondary education & 176 & 42.6 \\
\hline Tertiary education & 216 & 52.3 \\
\hline \multicolumn{3}{|l|}{ Marital status } \\
\hline Single & 77 & 18.6 \\
\hline Married & 324 & 78.4 \\
\hline Divorced & 9 & 2.3 \\
\hline Widowed & 3 & 0.7 \\
\hline \multicolumn{3}{|l|}{ Religion } \\
\hline Christianity & 262 & 63.4 \\
\hline Islam & 151 & 36.6 \\
\hline \multicolumn{3}{|l|}{ Occupation } \\
\hline Artisans & 106 & 25.7 \\
\hline Traders & 143 & 34.6 \\
\hline Civil Servants & 75 & 18.2 \\
\hline None & 89 & 21.5 \\
\hline
\end{tabular}


Table 2: Source of Information of COVID-19 among the Respondents

\begin{tabular}{lcc}
\hline Sources* & Frequency & Percentage \\
\hline Television & 313 & 75.8 \\
Radio & 287 & 69.5 \\
Social media & 235 & 56.9 \\
Newspaper & 128 & 30.9 \\
Friends \& Family & 36 & 8.7 \\
Health centers & 31 & 7.5 \\
NCDC SMS** & 3 & 0.7 \\
School & 3 & 0.7 \\
Religious center & 3 & 0.7 \\
\hline
\end{tabular}

*Multiple Responses, **NCDC SMS- Nigeria Centre for Disease Control Short Message Service

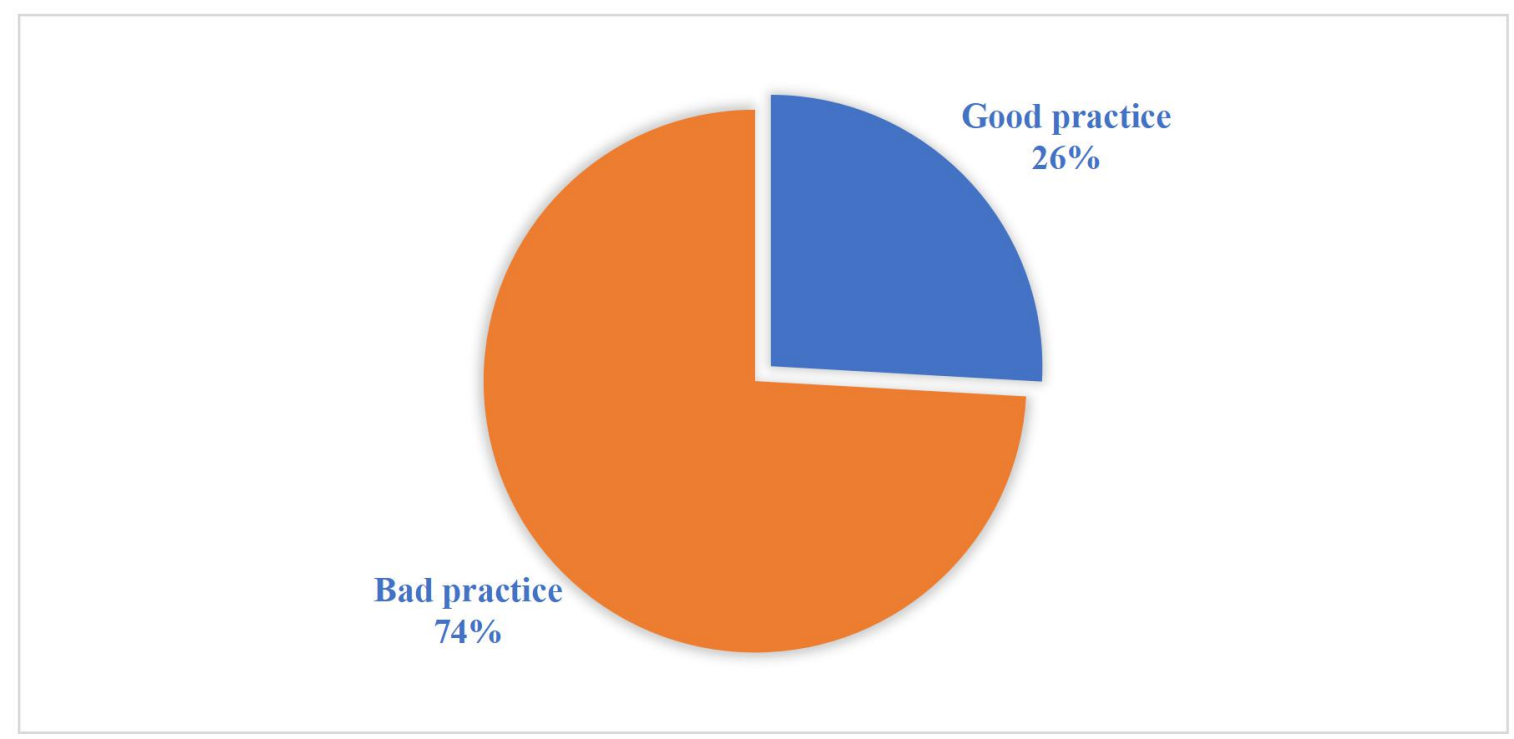

Figure 1: Level of COVID-19 Preventive Practice

Table 3 revealed the COVID- 19 preventive practice of which regular hand washing, 390 (94.4\%), was the highest preventive practice by the respondents followed by the use of face masks, $322(77.9 \%)$. The result presented in table 4 showed the factors associated with the practice of COVID-19 preventive measures; which includes the age of the women $(p=0.002)$, educational level of the women $(p=0.043)$, and marital status $(p=0.001)$. Respondents in the age group $\geq 40$ years had the highest prevalence (44.1\%) of good practice for COVID-19 
preventive measures. The prevalence of good practice was highest among participants that attained tertiary education (30.1\%) than non-tertiary education. Good practice was highest among divorced/widowed respondents (83.3\%). The level of practice across the diverse occupational groups of the respondents showed the unemployed (48.8\%) had the highest level of good COVID-19 preventive practice.

Table 3: COVID-19 Preventive Practices among the Respondents

\begin{tabular}{lcc}
\hline *Variables & Frequency & Percentage \\
\hline Regular hand-washing & 390 & 94.4 \\
Use of face masks & 322 & 77.2 \\
Use of hand-sanitizers & 249 & 59.7 \\
Maintaining social distancing & 243 & 58.3 \\
Covering your mouth properly when coughing & 133 & 31.9 \\
Self-isolation & 98 & 23.5 \\
\hline
\end{tabular}

Multiple Responses*

Table 4: Factors Associated with COVID-19 Preventive Practice

\begin{tabular}{|c|c|c|c|}
\hline \multirow[b]{2}{*}{ Variable } & \multicolumn{2}{|c|}{ Preventive Practices } & \multirow{2}{*}{$\begin{array}{c}\chi^{2} \\
\text { (p-value) }\end{array}$} \\
\hline & $\begin{array}{c}\text { Poor } \\
\text { practice }(\%)\end{array}$ & $\begin{array}{c}\text { Good } \\
\text { practice (\%) }\end{array}$ & \\
\hline
\end{tabular}

Age (in groups)

$\begin{array}{lcc}18-29 \text { years } & 167(74.9) & 56(25.1) \\ 30-39 \text { years } & 119(76.3) & 37(23.7) \\ 40+\text { years } & 19(55.9) & 15(44.1)\end{array}$

16.75

(0.002)

Educational Level

Primary/Secondary education

$154(78.2) \quad 43(21.8)$

Tertiary education

$151(69.9) \quad 65(30.1)$

4.11

(0.043)

Marital status

$\begin{array}{lll}\text { Single } & 40(51.9) & 37(48.1) \\ \text { Married } & 263(81.2) & 61(18.8) \\ \text { Divorced/Widowed } & 2(16.7) & 10(83.3)\end{array}$

Occupation 

Artisans
93 (87.7)
$13(12.3)$
2.422
Traders
$115(80.4)$
28 (19.6)
(0.490)
Civil Servants
$51(68.0)$
$24(32.0)$
None
$45(51.1)$
$43(48.8)$

Majority $338(81.8 \%)$ of the respondents are aware of physical violence against women and girls more than any other types of violence against women and girls (table 5). Sixty-four $(15.5 \%)$ of the respondents had experienced violence of one form or the other while 349 $(84.5 \%)$ had not experience violence of any form. Table 6 showed the violence experienced by the respondents. Majority, $57(89.1 \%)$ had experienced emotional violence closely followed by psychological violence, $51(79.7 \%)$. The partners' low income $(70.3 \%)$ and anger/hostility $(62.5 \%)$ were the most common causes of violence in their homes. About half, 31 (48.4\%) experienced violence as a result of staying at home during COVID-19 lockdown. The prevalence of violence against women and girls among the respondents as a result of the COVID-19 lockdown was 7.5\%.

Table 5: Knowledge on types of Violence against Women and Girls among Respondents

\begin{tabular}{lcc}
\hline *Types of violence against women \& girls known & $\begin{array}{c}\text { Frequency } \\
\mathbf{N = 4 1 3}\end{array}$ & Percentage \\
\hline Physical violence & 338 & 81.8 \\
Sexual violence & 256 & 61.9 \\
Emotional violence & 165 & 39.9 \\
Psychological violence & 82 & 19.9 \\
\hline
\end{tabular}

Multiple Responses*

Table 6: Violence experienced among Respondents

\begin{tabular}{lcc}
\hline *Variables & $\begin{array}{c}\text { Frequency } \\
\mathbf{n}=\mathbf{6 4}\end{array}$ & Percentage \\
\hline Types of violence experienced & & \\
Emotional violence & 57 & 89.1 \\
Psychological violence & 51 & 79.7 \\
Physical violence & 50 & 78.1 \\
Sexual violence & 26 & 40.6
\end{tabular}

Causes of violence experienced 
Partners' low income

Anger and hostility

Partners' exposure to violence during childhood

Adherence to strict beliefs

Alcohol and drug abuse

Condoning violence in a relationship

Low academic achievement of the partner
Experienced violence as a result of staying home during the Covid-19 lockdown

Multiple Responses*

The study further revealed that age $(\mathrm{p}=0.008)$ and marital status $(\mathrm{p}<0.001)$ had statistically significant association with violence experienced among the respondents. It was also seen that violence was higher among the older age group (26.5\%), respondents with lower level of education (16.7\%), divorced/widowed (75.0\%) and the unemployed respondents $(31.4 \%)$ (table 7). The relationship between level of COVID-19 preventive practice and experience of VAWG. There was a statistically significant relationship between level of COVID-19 preventive practice and experience of VAWG $\left(\chi^{2}=19.59 ; \mathrm{p}=0.001\right)$ as shown in table 8 .

Table 7: Factors Associated with Violence experienced among respondents

\begin{tabular}{lccc}
\hline Variable & \multicolumn{2}{c}{ Experienced Violence } & $\begin{array}{c}\chi^{2} \\
\text { (p-value) }\end{array}$ \\
& No (\%) & Yes (\%) & \\
Age (in groups) & & & \\
$18-29$ years & $182(81.6)$ & $41(18.4)$ & $\mathbf{1 3 . 9 2}$ \\
$30-39$ years & $142(91.0)$ & $14(9.0)$ & $\mathbf{( 0 . 0 0 8})$ \\
$40+$ years & $25(73.5)$ & $9(26.5)$ & \\
Educational level & & & 0.34 \\
$\quad$ Primary/Secondary education & $164(83.3)$ & $33(16.7)$ & $(0.559)$ \\
Tertiary education & $185(85.6)$ & $31(14.4)$ & \\
Marital status & & & $\mathbf{6 7 . 6 2}$ \\
$\quad$ Single & $50(64.9)$ & $27(35.1)$ & $\mathbf{( < 0 . 0 0 1 )}$ \\
Married & $296(91.4)$ & $28(8.6)$ &
\end{tabular}




\section{Occupation}

\begin{tabular}{lccc} 
Artisans & $81(76.4)$ & $25(23.6)$ & 6.389 \\
Traders & $125(87.4)$ & $18(12.5)$ & $(0.094)$ \\
Civil Servants & $58(77.3)$ & $17(22.7)$ & \\
None & $61(68.5)$ & $28(31.4)$ \\
\hline
\end{tabular}

Table 8: Relationship between Level of COVID-19 Preventive Practice and Experience of VAWG

\begin{tabular}{lccc}
\hline Variable & \multicolumn{2}{c}{$\begin{array}{c}\text { Level of COVID-19 } \\
\text { preventive practice }\end{array}$} & $\chi^{2}$ (p-value) \\
& Poor & Good & \\
\hline $\begin{array}{l}\text { Experienced violence as a result of staying home } \\
\text { during the Covid-19 lockdown }\end{array}$ & & & \\
No & $292(76.4)$ & $90(23.6)$ & $\begin{array}{c}\mathbf{1 9 . 5 9} \\
\text { Yes }\end{array}$ \\
\hline
\end{tabular}

\section{Discussion}

The ages of the majority $223(54.0 \%)$ of the respondents who participated in this study were between 18 and 29 years. This could be due to a higher population of younger women compared to older women in the selected local governments. Also, younger women are more than likely to be prone to different types of violence [16]. This result agrees with the findings of World Health Organization who reported that violence starts early in the lives of women and revealed the prevalence of VAWG among women from 15-29 years to be $31.1 \%$ [8].

The results revealed that almost all $410(99.2 \%)$ of the respondents acknowledged they were aware of the COVID-19. The majority 313 (75\%) of the respondents revealed that television and $287(68.8 \%)$ radio were their main sources of information on COVID-19. Television, radio, and social media remain the ways most people source the latest information in most rural-urban communities in Nigeria even though these sources can be used as a tool for misinformation, especially social media. According to Ngozika et al., social media platforms nowadays play huge roles in disseminating information at a very fast rate and these platforms have been violated by promoting fake news and instigating panics for the general public [17]. However, these results agree with the findings of Olapegba et al. who reported that respondents got to know about the COVID-19 pandemic mostly through social media and television [18]. 
Furthermore, the result revealed that frequent hand washing; 390 (93\%) was the most common COVID-19 preventive measures practiced by respondents since the pandemic. This result agrees with the findings of Alnasser et al. who reported most respondents frequently washed their hands and maintained social distancing as preventive measures against COVID19 [19].

However, it was revealed from the study that most 305 (74\%) of the respondents had a bad practice level for COVID-19 preventive measures. The factors associated with the level of bad practice level for COVID-19 preventive measures among respondents was varied across their ages, education, marital status, and occupations. Notably, respondents in the highest age $(40+$ years) category had a relatively higher prevalence $(44.1 \%)$ of good practice for COVID19 preventive measures than others.

This could be due to the perception among older-aged individuals especially when it has been declared that the COVID-19 virus affects mostly the vulnerable and older persons as stated by WHO [2]. Also, respondents who attained tertiary education showed better adherence to COVID-19 preventive measures than the secondary school degree holder, which could imply that respondents with tertiary education may be more sensitive to the effects of COVID-19. It could also be that higher level of education increases the knowledge seeking behaviour of an individual and thereby increases adherence to preventive measures. The increase preventive measures could also be influenced by their positive attitudes towards what others feel about their actions.

Accordingly, divorced respondents showed a better level of practice for COVID-19 preventive measures compared to married respondents while the respondents who are unemployed and respondents who work as civil servants generally showed a fairly average level of for COVID-19 preventive measures. Overall, these results were not in line with the findings of Alnasser et al [19] who reported most individuals over 15 years generally showed good practice for COVID-19 preventive measures but were in line with other studies such as Nzaji et al and Hills et al [20,21] who reported that individuals showed low levels of practice for COVID-19 preventive measures.

Violence against women and girls embodies several histories of unequal power relations between men and women leading to men's dominance and discriminatory act against women, which further prevents women from advancing [22]. This implies that violence against women and girls is a social injustice that subjugates women into a lower position compared to men. 
The results revealed that physical violence and sexual violence were the most common types of violence known to the respondents. This collaborates with the findings of Chandra-Mouli et al and UN [5,6]. The majority 349 (84.5\%) of the women had never known nor experienced any type of violence. A few 31 (7.5\%) of the women claimed they had experienced a type of violence as a result of staying at home during the COVID-19 lockdown. These results were not in line with the findings of Bakare et al who reported that up to $35 \%$ of women and girls experience different forms of violence in Nigeria [23]. This study also revealed that age and marital status were factors associated with the experience of violence as the prevalence of violence was relatively higher among the older age groups. The divorced women had the highest prevalence of violence. These results are in line with the findings of Bakare et al [23]. Concerning experiencing violence as a result of staying at home COVID-19, only a few respondents $31(7.5 \%)$ reported having experienced any form of violence as a result of staying at home during the COVID-19 lockdown or adhering to other COVID-19 guidelines in which the violence faced by the victim mostly include emotional and psychological violence. This low figure can be either attributed to the underreporting of domestic and gender violence in Nigerian homes or that COVID-19 lockdown has little effect on the rate of violence in the study areas $[4,23]$.

In conclusion, most women and girls within the study areas were aware of COVID-19 disease although they showed bad practice for COVID-19 preventive measures requiring better government policies centered on the adherence to COVID-19 preventive practice. Regular hand washing was the most common preventive practice against COVID-19. Violence against women and girls was present among the respondents of which emotional violence was the most common and was majorly caused by financial constraint which government can address by providing palliatives and incentives during the lockdown. It is worth of note that an aspect of COVID-19 preventive practices such as lockdown enforcement contributes to an increase in violence against women and girls. The findings of this research study can however be useful for further research on the finding of the links between COVID-19 preventive practices and violence among women and girls that can contribute to the attainment of the sustainable development goals coined out by the United Nations. 


\section{Acknowledgements}

The authors appreciate the effort of Dr S. A. Olowookere of the Department of Community Health, Obafemi Awolowo University, Ile-Ife, Osun-State for editing and proof reading this paper.

\section{References}

[1] World Health Organization. WHO announces COVID-19 outbreak a Pandemic Available from: http://www.euro.who.int/en/health-topics/health-emergencies/coronaviruscovid19/ news/news/2020/3/who-announces-covid-19-outbreak-a-pandemic. Accessed 20-7-2021.

[2] WHO. Coronavirus disease 2019 (COVID-19) situation report - 23. Geneva, Switzerland: World Health Organization. 2020. https://www.who.int/docs/defaultsource/coronaviruse/situation-reports/20200212-sitrep-20200223ncov.pdf?sfvrsn=20200241e20200219fb20200278. Accessed 15-5-2021.

[3] IPPF. Novel Coronavirus COVID-19. Infection Prevention and Control. 2020. https://www.ippfeseaor.org/sites/ippfeseaor/files/202004/Infection\%20Prevention\%20an d\%20Control\%20-\%20COVID\%2019\%20 \%20Resources\%20\%2002042020\%20\%28wecompress.com\%29.pdf. Accessed 7-3-2021.

[4] WHO. COVID-19 and violence against women: What the health sector/system can do. 2020. https://www.who.int/reproductivehealth/publications/emergencies/COVID-19VAW-full-text.pdf. Accessed 12-6-2021.

[5] Chandra-Mouli V. Amin A. Violence against women and girls: Forms, levels, consequences, causes, and growing commitment to address it. Department of Reproductive Health and Research, World Health Organization. 2020. http://archive.ipu.org/splz-e/dhaka14/mouli.pdf. Accessed 15-7-2021.

[6] UN Women. COVID-19 and ending violence against women and girls. 2020. https://reliefweb.int/sites/reliefweb.int/files/resources/brief-prevention-violence-againstwomen-and-girls-and-covid-19-en.pdf. Accessed 18-6-2021.

[7] Ellsberg M. Arango DJ. Morton M. Gennari F. Kiplesund S. Contreras M, et al. Prevention of Violence against Women and Girls: What Does the Evidence Say? The Lancet. 2014; 385: 1555-1566. doi: 10.1016/S0140-6736(14)61703-7.

[8] WHO. Global and regional estimates of violence against women. Sexual and Reproductive Health. 2015. 
https://www.who.int/reproductivehealth/publications/violence/9789241564625/en/. Accessed 20-6-2021.

[9] Abrahams N. Devries K. Watts C. Pallitto C. Petzold M. Shamu S, et al. Worldwide prevalence of non-partner sexual violence: a systematic review. Lancet. 2014; 383: 164854. doi: 10.1016/S0140-6736(13)62243-6.

[10] Feldman-Jacobs C. Clifton D. Female genital mutilation/cutting: data and trends, update 2014. Washington, DC: Population Reference Bureau.

[11] Lee-Rife S. Malhotra A. Warner A. Glinski AM. What works to prevent child marriage: a review of the evidence? Stud Fam Plann. 2012; 43(4): 287-303. Doi: 10.1111/j.17284465.2012.00327.x. PMID: 23239248.

[12] OSG. Oyo State Government. Population and Local Government Area and LCDAs. 2019. https://oyostate.gov.ng/

[13] Arifalo SF. Ayilaran CI. Effects of micro-credit scheme on agricultural production among members of farmers development union, Oyo State, Nigeria. Nigerian Journal of Agricultural Economics. 2012; 3(1): 59 - 68. Doi: 10.22004/ag.econ.267823. ISSN: 0794-4748.

[14] LitCaf. Ibadan History. 2016. https://itcaf.com/ibadan-history/

[15] Suresh KP. Chandrashekara S. Sample size estimation and power analysis for clinical research studies. J Hum Reprod Sci. 2012; 5:7-13.

[16] Le Maason V. Benoudiji C. Reyes SS. Bernard G. Violence against women and girls and resilience: Links, impacts and perspectives from the Chadian Context. 2015. Available from https://reliefweb.int/sites/reliefweb.int/files/resources/12011.pdf. Accessed 20-72021.

[17] Ngozika A. Obi-Ani, Anikwenze C. Isiani MC. Social media and the COVID-19 pandemic: Observations from Nigeria. Cogent Arts and Humanities, 2020; 7:1. Doi: 10.1080/23311983.2020.1799483.

[18] Olapegba PO. Ayandele O. Kolawole SO. Oguntayo R. Gandi JC. Dangiwa AL, et al. (2020). A preliminary assessment of novel Coronavirus (COVID-19) knowledge and perceptions in Nigeria. 2020; doi: https://doi.org/10.1101/2020.04.11.20061408.

[19] Alnasser AHA. Al-Tawfiq JA. Al-Kalif MSH. Shahadah RFB. Almuqati KSA. AlSulaiman BSA, et al. Public knowledge, attitudes, and practice towards COVID-19 pandemic in Saudi Arabia: A web-based cross-sectional survey. Med Sci. 2021; 9:11. Doi: https://doi.org/10.3390/medsci9010011. 
[20] Nzaji K. Mwamba NG. Miema MH. Umba KN. Kangulu IB. Ndala BDB, et al. Predictors of non-adherence to public health instructions during the COVID-19 pandemic in the Democratic Republic of Congo. J Multidisciplinary Healthcare, 2020; 13: 12151221.

[21] Hills SJ. Eraso Y. Factors associated with non-adherence to social distancing rules during the COVID-19 pandemic: A logistic regression analysis. BMC Public Health. 2021; 21(1): 352. Doi: 10.1186/s12889-021-10379-7. PMID: 33581734.

[22] UN Women. A Framework to Underpin Action to Prevent Violence against Women. 2015. $\quad$ https://www.unwomen.org/en/digital-library/publications/2015/11/preventionframework

[23] Bakare MO. Asuquo MDA. Agomoh AO. Domestic violence and Nigeria women - A review of the present state. Nigerian Journal of Psychiatry. 2010; 8(2). Doi: 10.4314/njpsyc.v8i2.57620. 